\title{
The St. Petersburg Media in Transformation
}

\author{
Svetlana Pasti
}

\begin{abstract}
The article describes the transformation of contemporary Russian media in the dual framework of common trends initiated and set to a great extent from the centre of power in Moscow, on the one hand, and specifics pertaining in the regions, on the other. As common trends characterising the post-Soviet society and media we note capitalization, westernization, commercialization and corruption. Their specific character was formed by the political and economic conditions pertaining in St. Petersburg from the end of the 1990s to the beginning the 2000s. The article is based on an empirical study of St. Petersburg media conducted 1998-2001. The data consist of pilot interviews with eleven experts in 1998 , in-depth interviews with thirty journalists in the editorial offices of the eight basic media in 1999, and a survey of eleven experts in 2001. Asking in what ways the common trends dovetail into the local context, the article describes the conditions for journalism and its emerging characteristics. On the one hand, the study reveals crucial changes after the decade of reforms, such as the intensive development of informational and advertising services in society and commercialization of media and journalist's labour. On the other hand, the study notes the forces of continuity deriving from the fact that the media and journalists formerly served the interests of the political and economic groups rather than the interests of the public.
\end{abstract}

Key Words: media boom, bankruptcy, corruption, transforming russia

\section{Introduction}

St. Petersburg was the capital of Russia twice: from 1712 to 1728 and from 1728 to 1918. The city was the cradle of Russian journalism, where there emerged the first printed newspaper and daily (Sankt-Peterburgskie Vedomosti 1728), the first evening paper (Vechernyaya gazeta 1866) and the first free paper (Kopeika 1907) (Bogdanov and Vyazemsky 1971: 66; Voroshilov 1999: 50). In the Soviet era, the city courted fame as the cultural capital; in the post-Soviet era, it gained fame as the criminal capital. At the start of the 1990s, the city became the stronghold of new thinking in Russia. After the defeat of Anatoly Sobchak in the elections of 1996 and the rise to power of Vladimir Yakovlev, the city "started to lose its grip on the overall development in Russia and became one of the largest, but provincial, centers" (St. Petersburg in the 1990s. Decem- 
ber 2000: 7). Beginning in 2000, when Vladimir Putin, a native of Leningrad, became President of Russia, the state of the city again gradually changed. It is set at the center of the North-west Federal District; the political power of the present Russian authority is partly being moved to St. Petersburg.

St. Petersburg stands as a good indicator of post-Soviet development in a national scale - better than Moscow, which is unique in its own scale. Being one of 89 subjects of the Russian Federation and at the same time the second Russian megalopolis, St. Petersburg fully experienced all transformational processes occurring in society and media. Crucial developments in the media structure and media system began to take place at the turn of the decade from the 1980s to the 1990s, along with the collapse of the Soviet Union, followed by a wave of changes along with the 1990s (Vartanova 2001; I. Zassoursky 2002, 2004). This study looks at the final wave of the changes in the 1990s. Since 2001, the overall picture has remained more or less the same, but naturally there have been many developments regarding individual media and media professionals. The article is based on my empirical study on working journalists. The study was conducted in 1998-2001 in St. Petersburg and presented as a Licentiate's thesis in spring 2002 at the University of Tampere, Department of Journalism and Mass Communication $^{1}$. The data consist of pilot interviews conducted in 1998 with eleven experts, indepth interviews conducted in 1999 with thirty journalists in the editorial offices of the eight basic city media and an inquiry directed at eleven experts in 2001.

\section{Media Market}

In St. Petersburg the media structure developed dynamically (Zassoursky 2001: 12; Sredstva Massovoi Informatsii Sankt-Peterburga i Leningradskoi oblasti 1999: 3). In comparison with the Soviet period, the quantity of the city media increased many times over, from 118 in 1991 to more than 4000 in 2001 (Yuri Tretyakov, vice chief of the committee for mass media and public relations of the City Administration of St. Petersburg, interview 2001). This clearly showed that the amount of new media had come to dominate the information market. Approximately every week, ten new print media were registered in the city, fifteen new media over the north-western part of Russia (ibid.). Table 1 presents the data on media registered on 1 April 2001 by the North-Western Direction of the State Committee of the Russian Federation on the mass media:

Table 1. Registered Media until 01.04.2001

\begin{tabular}{lcc} 
Media & North-Western Part of Russia & St. Petersburg \\
\hline Total mass media & 5883 & 3211 \\
Newspapers & 2895 & 1380 \\
Magazines & 1519 & 1237 \\
Information agencies & 301 & 178 \\
TV programs & 608 & 227 \\
Radio programs & 388 & 120 \\
Other electronic media & 124 & 3 \\
\hline
\end{tabular}

In early 2001, the North-Western Direction of the State Committee of the Russian Federation on the mass media in St. Petersburg issued 815 licenses permitting polygraphic activity, of which 146 were state licenses, 69 municipal and 600 non-state licenses. 
According to its data, in the north-western region of Russia 30 enterprises specialized in the production of newspapers. This undermined the old monopoly in terms of output of the press and created premises for the development of competition in poligraphy.

The specialists noted that, remarkably, the peak of registration occurred before the expansion of pre-election campaigns and after that not many media more appeared (ibid.). That is, the media sector swelled for political needs and narrowed for everyday needs. Thus, in 1999 in the city, there were more than 600 registered newspapers, however of these only 150 were operational (Voroshilov 1999: 210). The experts explained that the politicization of the acting media was not only due to their dependence on political and economic sponsors who participated in the fight for power, but also to their extreme poverty in the means of subsistence:

All Russian newspapers await any elections with impatience because then the gold will rain down on the indigent press. Today such newspapers as: Nevskoe Vremya, Chas Pik one and another Chas Pik, Vechernii Peterburg do not pay salaries. The journalists work absolutely disinterestedly, earning additionally from hack-works, writing books and making adverts. Everybody hopes that somebody will buy somebody, but any newspaper demands huge investments. Vechernii Peterburg and Smena have already been burnt by this (Marina Goncharenko, deputy of editor-in-chief of the daily Smena, interview 1998).

In turn, the journalists testified that by producing commissioned materials during the election period, it was possible to earn money for a car, a flat and even a well-to-do existence for the year ahead. The majority tried to take advantage of these "hot days". In the calm or between elections, life entered its normal course and then the media turned to the needs of the audience.

The city information market included periodicals; newspapers, magazines, newsletters; electronic media; tele-radio companies, radio programs, TV programs, video programs; information agencies (Sredstva Massovoi Informatsii Sankt-Peterburga $i$ Leningradskoi oblasti 1999). Like the traditional information press, specialized newspapers took a more and more active role. Thus, in 1998, there were 128 different themes, among which advertising (31) and business \& financial (12) were the most numerous. Among the city entrepreneurs, there were such authoritative newspapers as Delovoi Peterburg and Delovoe obozrenie. In the mass audience, tabloid weeklies Peterburg Ekspress and Kaleidoskop were much in demand. Free advertising newspapers such as Astok-press; Privet, Peterburg; Utro Peterburga; Metro, Reklama-pluys, Ekstra-Balt had been distributed near metro stations every day, whereas on Saturdays every family took from its post box the latest issue of the free advertising newspaper Tsentr-pluys (Voroshilov 1999: 50-51). The city market for magazines catered to various interests and tastes. Thematically it embraced 35 directions, from editions on anomaly phenomena (Paranormalnyi Peterburg) to national-cultural (Ukraintsy $i$ Peterburg) and informational technologies (Ves kompuytornyi mir Sankt-Peterburga).

The experts estimated St. Petersburg to be a city of high media saturation. There were 28 local TV programs, of those 25 non-state, as well as 31 local radio programs, of which only one was state run. Monthly, more than half a million copies of periodicals (577.5 thousand) were subscribed to. This was not a great deal, amounting to only 122 copies of newspapers or magazines per 1000 inhabitants. This figure was considerably below the average subscription index in the country. The experts explained the low level of subscription by the high subscription rate and the developed net of the retail trade. Thus, the average subscription rate was 27 rubles 83 kopecks, which exceeded the average subscription rate in Russia by a factor of 1.48 (Public expertise 2000: 677) ${ }^{2}$. 
The standard of living determined the purchasing power of the population. In St. Petersburg, the living standard and housing conditions remained very low. In 1998, almost one third ( $27 \%$ of the population) had incomes less than the official living wage (St. Petersburg in the 1990's.December 2000: 7). According to the data of the city administration, two million (the city has 4.7 million inhabitants) received social benefits such as pensions, the family allowance, unemployment benefits and other social benefits (Osnovnye itogi...2001: 40). In the experts' opinion, information saturation of the region occurred at the expense of TV and radio broadcasting (Public expertise 2000: 677).

One further reason why the city press was not in high demand among readers, as the experts argued in 1998, lay in its engagement and lack of high quality:

For the audience it is a problem to get information because the journalists mix news with comments and although there is Internet from which it is possible to take any information, it is not available for the majority, the majority of the population receives news mainly from the television. I am not a poor man, but for next half year I shall subscribe to not one St. Petersburg newspaper, there is nothing to read. The professional level is low, facts are interpreted freely, there is no division between fact and the appraisal of the journalist (Vladimir Gelman, researcher at the St. Petersburg European University, interview).

Information communication technologies were developing intensively in the city. Thus, regarding the bulk of services connected with Internet, St. Petersburg left behind all regions except Moscow (Zassoursky 2001: 228, 225). Fifty-four organizations provided access to the resources of the global net. The number of inhabitants who used Internet had reached 500 thousand. More than 1.5 million city-dwellers used the computer in everyday life. Of these, more than $30 \%$ had a personal computer at home. Specialists noted the rapid growth of cellular radio; at the end of 2000, nearly 350,000 used cellular radio services. Cable television was developing actively. For instance, the number of subscribers to the cable net reached 40 thousand in 2000 (Osnovnye itogi 2001: 1415).

In summary, it can be noted that the St. Petersburg media market was dynamic, politicized, diverse and supersaturated. Its dynamics was caused firstly by the favorable political situation of the 1990s when the state (the center and the local authorities) did not command the forming media market; the development was going more over market laws according to supply and demand The other matter was that the market was deviant and the political needs often formed demand, the media were permanently required as tools for propaganda by different political and business groups fighting for power. On the other hand, the splash of specialized editions, especially advertising and business press, testified to the healthy economic development of the city as a big industrial and cultural center. The intensive development of new communication technologies also testified in favor of this trend. The fact of the high media saturation predicted that the media sector would receive large investments from business, which in turn was interested in media as a public mass PR-machine for promoting goods and services. This also presupposed promoting pluralistic and varying information to the audience. The fact that a new edition could easily appear in the information market also showed that the market was not yet formed: The market was significantly amorphous and uncertain; the competition did not get development. The large amount of media created an opportunity for the full employment of journalists. 


\section{Capitalization}

By 1998, practically the whole city media sector was privatized: " $90 \%$ of the newspapers of St. Petersburg were joint-stock companies" (Namsaraeva 1998: 12). In the data for 1999-2000, the share of private newspapers and magazines was $90.6 \%$. The aggregate volume of printed copies of private newspapers and magazines was 15,348,732 copies a week, whereas the state newspapers and magazines had an aggregate volume of 1,584,665 copies a week. The aggregate capacity of private TV transmitters was 99.35 kilowatts, the aggregate capacity of the state and municipal TV transmitters was $50 \mathrm{~kW}$. The whole share of private TV transmitters was $66 \%$. In contrast, radio remained more in state than in private ownership. The share of private radio transmitters was only $25 \%$ and their aggregate capacity was $87.2 \mathrm{~kW}$, whereas the aggregate capacity of the state and municipal radio transmitters was $260 \mathrm{~kW}$ (Public expertise 2000: 682, 24). The experts took the fact of the prevailing private media over state media as one of the basic indicators determining the market type of journalism development in the region. Among six other types identified by the experts, the market model was the most progressive pertaining to such major industrial regions as the Urals, Siberia, the center of Russia, Moscow and St. Petersburg, a total of twelve regions of the Russian Federation with $23 \%$ of the population (ibid., 117).

Sampling of the news media for the study was done on the advice of the St. Petersburg experts at the end of 1999. The selection of the media was pursued to obtain various types, based on the following criteria: to cover the most influential city media; traditional (established in the Soviet era) and new (established in the post-Soviet era); print (dailies, weeklies) and electronic (radio and television); profit-making and non-profit-making; state and private; local media and Moscow branches.

In this way, the selected media included TRK Peterburg (Tele Radio Company) consisting of the 5th TV channel (the former Federal TV channel) and Radio Peterburg, the first independent FM Radio station Baltika, all three dailies: Sankt-Peterburgskie Vedomosti, Smena, Vechernii Peterburg; the regional edition of the central daily Komsomolskaya Pravda, and the first city tabloid, weekly Peterburg Express. Below, Table 2 presents the media sample with the distribution and circulation of the media, type of media ownership and the media owners. The data on the circulation are provided by the handbook of 1999 (Sredstva massovoi informatsii Sankt-Peterburga $i$ Leningradskoi oblasti 1999).

These eight leading news media represented different informational journalism in the city. Moreover, the given sampling of the media reflected the ongoing process of monopolization and concentration of the mass media in the hands of political and financialindustrial groups including foreign capital. Thus, five media (all traditional) out of eight belonged to the local authorities (the city and the regional governments and the city council); three media (new) had foreign investors as founders.

For the leading informational media based in the Soviet era, the transition to market relations became decidedly painful. Having been successful as state media, they showed their inability and insolvency as subjects of the market, although they persisted there with their former names largely owing to their cooperation with the local authority. The quotations from the interviews with the experts outline the picture of the state of these newspapers in1998:

The traditional newspapers were on the brink of collapse: loss of the state financing, five to seven times drop in circulation, non-payment of salaries (Igor Sidorov, managing director of the St. Petersburg Union of Journalists). 
Table 2. Sampling of Media and Their Characteristics toward the End of 1999

\begin{tabular}{|c|c|c|c|}
\hline Type of Media & Distribution & Ownership & Shareholder \\
\hline $\begin{array}{l}\text { TRK Peterburg } \\
\text { 5th TV Channel }\end{array}$ & $\begin{array}{l}\text { St. Petersburg and the } \\
\text { Leningrad region }\end{array}$ & state-private & $\begin{array}{l}51 \% \text { : - the City ( } 38 \%) \text { and } \\
\text { the regional governments } \\
(13 \%) 49 \% \text { - private } \\
\text { capital: } \\
\text { Promstroibank }-17.5 \% \\
\text { BaltOneksimbank }-17.5 \% \\
\text { Inkombank - } 14 \%\end{array}$ \\
\hline
\end{tabular}

\begin{tabular}{|c|c|c|c|}
\hline $\begin{array}{l}\text { TRK Peterburg } \\
\text { Radio Peterburg }\end{array}$ & $\begin{array}{l}\text { St. Petersburg and the } \\
\text { Leningrad region }\end{array}$ & state-private & the same shareholders \\
\hline Radio Baltika & $\begin{array}{l}\text { St. Petersburg,the } \\
\text { Leningrad region and } \\
\text { Karelia }\end{array}$ & $\begin{array}{l}\text { private with foreign } \\
\text { investment }\end{array}$ & $\begin{array}{l}\text { Scandinavian corporation } \\
\text { (headquarters in Sweden) } \\
\text { St. Peterburg brewery } \\
\text { Baltika }\end{array}$ \\
\hline $\begin{array}{l}\text { Daily } \\
\text { Sankt-Peterburgskie } \\
\text { Vedomosti } \\
\text { the former Leningradskaya } \\
\text { Pravda,organ of the } \\
\text { regional CPSU Committee }\end{array}$ & $\begin{array}{l}\text { St. Petersburg and the } \\
\text { Leningrad region } \\
\text { Circulation over } 145000\end{array}$ & state-private & $\begin{array}{l}\text { the city government, ZAO } \\
\text { Gazeta Sankt- } \\
\text { Peterburgskie Vedomosti }\end{array}$ \\
\hline
\end{tabular}

\begin{tabular}{|c|c|c|c|}
\hline $\begin{array}{l}\text { Daily } \\
\text { Smena } \\
\text { the former Smena, organ } \\
\text { of the regional Komsomol }\end{array}$ & $\begin{array}{l}\text { St. Petersburg and the } \\
\text { Leningrad region } \\
\text { Circulation: } 41000\end{array}$ & state- private & $\begin{array}{l}\text { Zakonodatelnoe Sobranie } \\
\text { Sankt-Peterburga (the city } \\
\text { Parlament) ZAO Smena }\end{array}$ \\
\hline
\end{tabular}

Committee (Young

Communist League)

\begin{tabular}{|c|c|c|c|}
\hline $\begin{array}{l}\text { Daily } \\
\text { Vechernii Peterburg } \\
\text { the former Vechernii }\end{array}$ & $\begin{array}{l}\text { St. Petersburg and the } \\
\text { Leningrad region } \\
\text { Circulation is } 20000\end{array}$ & state-private & $\begin{array}{l}\text { the city government the } \\
\text { banks: Sankt-Peterburg, } \\
\text { Oneksim }\end{array}$ \\
\hline
\end{tabular}

Leningrad, organ of the

city CPSU Committee

\begin{tabular}{|c|c|c|c|}
\hline $\begin{array}{l}\text { the St. Petersburg edition } \\
\text { of the central leading daily } \\
\text { Komsomolskaya Pravda }\end{array}$ & $\begin{array}{l}\text { St. Petersburg and North- } \\
\text { western region in Russia } \\
\text { Circulation is } 40000 \text { on } \\
\text { Fridays is } 140000\end{array}$ & private & $\begin{array}{l}\text { Oneksimbank Izdatelskii } \\
\text { Dom Komsomolskaya } \\
\text { Pravda }\end{array}$ \\
\hline $\begin{array}{l}\text { Weekly } \\
\text { Peterburg Express }\end{array}$ & $\begin{array}{l}\text { St. Petersburg and the } \\
\text { Leningrad region } \\
\text { Circulation is } 50000\end{array}$ & $\begin{array}{l}\text { private with foreign } \\
\text { investment }\end{array}$ & $\begin{array}{l}\text { Izdatelskii Dom } \\
\text { Komsomolskaya } \\
\text { Pravdathe Norwegian } \\
\text { concern Apressen }\end{array}$ \\
\hline
\end{tabular}

The total circulation of all five dailies is less than the circulation of one any of them before (Yuri Vdovin, deputy in chief of the St. Petersburg Public Human Rights Organization Citizens' Control).

Among five dailies none was thriving, of these Sankt-Peterburgskie Vedomosti, the former Leningradskaya Pravda had the best position (Sergei Shelin, deputy of the daily Vechernii Peterburg).

Although Sankt-Peterburgskie Vedomosti began to publish its color supplement in Helsinki the daily had to stop it a few months later because of the high cost 
(Yuri Vdovin, deputy in chief of the St. Petersburg Public Human Rights Organization Citizens' Control).

In June 1998, five newspapers did not pay salaries to the journalists: Smena, Nevskoe Vremya, Peterburgskii Chas Pik, Chas Pik and Vechernii Peterburg (Marina Goncharenko, deputy editor-in-chief of the daily Smena).

The media chosen for the sample clearly illustrated the character of media privatization in St. Petersburg. One could discern three stages of the process of privatization. The first stage of "primary" privatization happened at the beginning of the 1990s. It was distinguished by getting legitimate "freemen" from the former organs of the CPSU and the Soviet structures: the President's Decree on 6th November 1991 on the dissolution of the Communist Party, the Laws on the Mass Media $(1990,1991)$ and the Constitution (1993). The media really became free, and mainly the staff of editorial offices became founders of editions and started reforming their own structure, staff policy, content of outlets and other innovations. At that time, the first money earned from advertisements appeared in the editorial cashbox.

Thus, in the daily Vechernii Peterburg in March 1991, the month's revenue from advertisements exceeded the profit of the whole previous year. The salaries of everyone working in the editorial office began to differ and were held secret from the others (Voroshilov 1999: 224, 272). In some media, for instance the daily Sankt-Peterburgskie Vedomosti, the workforce retained for itself a controlling amount of the shares and divided the other part of the shares between the local authorities (the city administration $-25 \%$ ) and bankers (the bank Rossia -20\%) (Alexander Yurkov, deputy of the daily Sankt-Peterburgskie Vedomosti, interview 1998). With the termination of state subsidies for the media and their own unskilled management, newspapers came to experience a severe lack of funds both for production and payment of salaries.

In the middle of the 1990s, the second stage of media privatization can be defined as "bankomania" when the media tried to attract financial capital, basically the banks, as they seemed the most solvent among other alternatives. The city newspapers were sold to the banks and for this received financial support. However, the new owners did not regard media as sources of economic profit, but rather as tools for political pressure in the elections. They did not invest capital in the media and did not develop them as enterprises. The editorial managers were hardly competent in media economy. In 1998, the managing director of the St. Petersburg Union of Journalists, Igor Sidorov, outlined the relations between the newspaper and its owner as follows:

A trivial story is when the bank bought the newspaper (as it was with Astrobank, which bought the daily Smena or the bank Sankt-Peterburg, which bought the daily Vechernii Peterburg); it gave the newspaper a lot of credit owing to which the newspaper lived peacefully for 1.5 to 2 years. When the money was gone the bank gave not one kopeck more. However, the newspaper continued to publish gradually getting into debt. When the debts achieved a huge size, the typical procedure was undertaken: the newspaper was declared bankrupt, publishing rights were passed to another juridical person and the newspaper began to publish in the name of the new juridical person. The standard situation when there are heaps of debts to the printing house, the state and others, but nobody can or will pay. The liquidation of a bankrupt firm is conducted with the liquidation of its debts. The last time such a procedure was undertaken was with the newspapers Smena, Peterburgskii Chas Pik, Chas Pik. 
The third stage of "the new re-division" of media ownership or re-privatization can be noted at the end of the 1990s, when bankrupt media again had to seek new owners who could somehow pay the expenses for production and the salaries of the workers. Mainly, those who were solvent were the local authorities and major financial capital. Journalists were finally put out of media ownership, and they did not even know now who their new owners were. Thus, in July 1999, the daily Vechernii Peterburg was declared bankrupt, there were salary arrears for the last two years, the journalists got 500 rubles every month and they received nothing for their shares, which were sold to the new owners. In November 1999, the journalists did not know and were not even interested in who their new owners were. For them, the most important question was getting their unpaid salary and increasing their present salary. The average journalist's salary was from 2 to 4 thousand rubles (50-100 US dollars). In the daily Sankt-Peterburgskie Vedomosti, journalists were forced to sell their shares to the daily's administration, and at the end of 1999 there were no journalists holding shares.

At that time, when the traditional media lived from hand to mouth and suffered from the loss of professional staff, the new gutter press arose, secured circulations and gained people's sympathy. This quotation is from the interview of 1998 with Igor Sidorov, managing director of the St. Petersburg Union of Journalists:

It cannot be liked because it shocks the public. Here are wild headlines, terrible from the point of view of an intelligent man. But they publish, increase circulation, and pay salary to the journalists. In contrast to the traditional press, obsessed rather by messianic moods, these newspapers had an idea about journalism as independent business. They strove to seize a seller's market, a consumer and an advertiser.

Among the most successful city editions there were the weeklies Peterburg Express and Kaleidoscop. Both were distributed mainly by retailers. Peterburg Express was started in 1994 by the central newspaper Komsomolskaya Pravda as the first yellow newspaper in the city. After the concern Kaleidoscop emerged and "bloomed" in the form of 7-8 kinds of different tabloids with a joint circulation of over 4-5 million, copies were delivered over the whole country. Interestingly, the audience of these editions comprised very different readers. Marina Goncharenko, deputy editor-in-chief of the daily Smena described it as follows:

The unprecedented blooming of the yellow editions of the concern Kaleidoscop emerged in the most intelligent city - Peterburg and went out to the national market. This weekly was a horror. When you enter the metro you see absolutely different people: those who have black fingernails - they did hard physical work; those who have manicured fingernails - they are sellers; you see the tired face of the teacher. And all of them in spite of social status and difference in education are reading Kaleidoscop.

As Igor Sidorov notes, "Everybody passing on the street and coming to the newspaper kiosk thinks what should I buy. And the majority buy Kaleidoscop and very few people buy Izvestiya. Kaleidoscop is the yellow newspaper of completely gutter content, 4 million copies in a week on beautiful glossy paper with wonderful photos".

The choice in favor of entertaining editions obviously testified to the political indifference of the reader and his/her curiosity as an inhabitant - what happened and to whom? Elena Vartanova (2001: 135) considers readers' and viewers' priorities in favor of infotainment to be an essential factor in the pressure of the audience on advertisers 
and producers who have to take into account new tastes and demands. In the St. Petersburg market, the Moscow editions were in high demand. Once a week they published the Petersburg pages in their outlets and this became the best selling form - combining central and local news. The most popular newspapers were Argumenty i Fakty, Novaya gazeta, Moskovskii Komsomolets, Komsomolskaya Pravda. The Moscow capital, mainly bank capital using the language of compromises with the local authority and observing certain rules of play, was actively promoted in the media market. The journalists from the new media invested in by Western and Moscow capital confirmed that the local authority was beyond the reach of their criticism.

The expansion of Moscow was going on in the television air. Thus, the Moscow channels TV6, TV Tsentr, 11th channel successfully competed with the local programs. As Alexander Yurkov, deputy of the daily Sankt-Peterburgskie Vedomosti, noted in 1998:

Today all the press has been brought to its knees economically, the main media have been bought up, privatized either formally or through allotment of shares. In St. Petersburg I know who feeds every newspaper. I am a member of the commission on the licenses for all media, we note that today Moscow channels increasingly seize television, the local entrepreneurs are not in a position to make transmission for 10-20 hours. Our 5th channel is in a critical state. The situation is such that the media become more dependent ... here censure is sharper, here public interests all disappear.

After 59 years of broadcasting with the status of the third national program of television, the St. Petersburg- 5th channel was equated with other regional television studios and its frequency was given to the new channel Kultura financed by the state budget according to the President's decree of 1.1.1997 (Media in CIS 1999: 228-229). Before the loss of the national status of television, in the city an attempt was made to turn the 5th channel into true public television for all Russia by establishing the monitoring council, but these efforts turned out to be unsuccessful. Yuri Vdovin, deputy in chief of the St. Petersburg Public Human Rights Organization Citizens' Control, remembered this in 1998 as follows:

The idea did not find support anywhere either in the centre - Federal Service of TV and Radio Broadcasting (FSTVRB), the Duma, the Union of Journalists, or at home: the local executive and legislative authorities, the Union of Journalists, the administration of the 5 th channel.

In August 1998, St. Petersburg television and radio were privatized and given the new name TRK Peterburg (Voroshilov 1999: 56, 218). The owners of the company were now the city and regional (oblastnoe) governments (51\% shares) and private capital (49\%): Promstroibank, BaltOneksimBank, Inkombank, some of the shares remained for sale. After privatization, the number of employees in the company was reduced by a factor of 6: radically, out of 2500 employees, only 750 were invited to continue their work. On radio, out of 650 only 108 workers were engaged, of them, 40 journalists. None of the journalists participated in buying the shares of the company.

The city administration as a whole owned an insignificant part of the shares in the media sector, approximately only $8-10 \%$ of all media. However, it held a controlling amount of the shares of the main city TV channel (the 5 th channel) and main radio broadcaster Peterburg together with the regional government, and it also held $25 \%$ of the shares of the main daily Sankt-Peterburgskie Vedomosti. The daily possessed exclu- 
sive rights to publish the city government's decrees and other important decisions concerning city affairs. The regional authorities (the regional government and municipal administrations) owned $60 \%$ of the shares in 180 newspapers of the Leningrad region. The district administrations of St. Petersburg have 70 of their newspapers (Yuri Tretyakov, vice chief of the committee for the mass media and the public relations of the City Administration of St. Petersburg, interview 2001).

The local experts argued that, by the middle of 1998, practically all the city media had been privatized in such a way that the local authorities mainly had no control except the ability to block allotment of shares. The governor had the option to influence the whole media sector to such an extent that no newspaper, not even the free ones, dared to criticize him. The interviews with respondents confirmed this, as in one excerpt from an experienced journalist working in the city press:

The newspaper cannot exist out of the society just like a man out of power in this country. If the newspaper has foreign owners it does not want to damage its relationship with the city authority. For instance, the newspaper St. Petersburg Times or our newspaper never seeks any quarrel with the governor. Where is independence here? One time I came and proposed material about Yakovlev, the governor. I said that I do not like this, I want to write about this. I came to the Moskovskii Komsomolets, it is the Moscow franchising type of newspaper that has some independence from the city. This is self-censorship of the editors who want to keep afloat. If they do not do this, the newspaper will not come out.

The sample of the leading informational media in St. Petersburg clearly showed the focus of participation of the local authority in media privatization. The city experts characterized St. Petersburg at the end of the 1990s as a semi-provincial city with limited finance, a narrow market for advertisements, low purchasing power of the population, and the lost national TV channel (the 5th channel came to be regional). Summarizing the peculiarities of capitalization in the media sector, one should emphasize that mainly the leading informational media were noted by the authority as valuable objects for privatization. That is, news had been formerly perceived rather in a political than an apolitical context. Vladimir Gelman, researcher at the St. Petersburg European University, argued in 1998 that:

Although it is not obvious that the media influenced the audience, nevertheless different financial-industrial groups struggled to control the media in the hope of political dividends in the next parliamentary, presidential, or governor's elections. The successful experience of the past presidential campaign of 1996 convinced them that the mass media can be effectively used as a tool in the indoctrination of the population. Between the elections and just before them the media were used as instruments of information wars. The fight for power between different political groups with the help of the media provided a plurality of information to the public that did not at all mean it was objective.

\section{Journalists in the Labor Market}

The question 'how many journalists work in St. Petersburg' stumped the local experts in Smolnyi in the committee of the mass media of the city administration, in the NorthWestern Direction of the State Committee of Russian Federation on the mass media, in the St. Petersburg Union of Journalists, in the Faculty of Journalism of the State University. Everyone argued that nobody had ever counted how many journalists work in 
the city. In the words of Vladilen Kuzin, lecturer at the St. Petersburg State University (interview 2001), in the Soviet era there was some card-index on the working journalists in the regional party committee, but it was not complete and now it is difficult to say whether it was kept or not.

In the words of Vsevolod Bogdanov, chair of the Russian Union of Journalists, the number of Union members is 100,000 from 80 regions of Russia (Bogdanov 2001: 63). Kuzin mentioned the same number, 100,000, regarding all media workers in the Russian mass media (Kuzin 1998: 69).

The St. Petersburg experts preferred to refer to the number of members of the St. Petersburg Union of Journalists. Thus, Yuri Tretyakov, vice chief of the committee for mass media and public relations of the City Administration of St. Petersburg (interview 2001), said about 2100 members. Elena Sharkova, vice chief of the St. Petersburg Union of Journalists (2001), mentioned about 2300 members, of which 1000 working journalists of pension age and 500 retired journalists not working, but continuing as members of the Union. The number of young journalists under 30 is insignificant. In her words, in the city there are practically no unemployed journalists, there are many editions on the market that are in need of staff.

In order to define the characteristics of the journalist population in the city, I conducted an expert inquiry among the representatives of the organizations mentioned and some heads of the city media. The chosen experts had solid experience of St. Petersburg journalism (11-45 years) and vast networks in the media sphere. Seven questions were formulated in the questionnaire and eleven experts were interviewed in April 2001. The results were obtained by statistical measurement of the average score in distribution. According to the results of the inquiry, there were fewer than five thousand journalists employed on a full-time basis in the city. Among them more than half were females. Among female journalists, more than one third were under 30 years, over one third were from 31 to 45 years, over one fifth were from 46 to 55 years females and one tenth were females over 55 years. Among male journalists more than one third were under 30 years, one fourth were from 31 to 45 years, one fifth were from 46 to 60 years and a few were over 60 years. More than half of the working journalists had a professional education, among the young generation half of journalists had a professional education.

The experts were asked to compare the journalist population in St. Petersburg in the Soviet and post-Soviet eras with respect to gender, age and education. According their judgment, in the Soviet era there were fewer female journalists than male journalists; the number of young journalists was proportionate to old journalists; several times more journalists had professional education than had not. In the past decade, many females have come into journalism and the proportion between females and males turned in favor of females; young journalists under 30 years were almost as numerous as old journalists; the journalists with professional education accounted for more than half.

Admitting the relativity of the results obtained from the expert inquiry (in the city there was no database of the journalists' population), one should note that the inquiry shows the same qualitative changes in the structure of the journalist population in the city that was found in domestic studies on the national population of journalists. Thus, this expert inquiry revealed that in the past decade, St. Petersburg journalism became more feminized, younger and less professionally educated. According to data from sociological studies conducted in the 1990s by Moscow State University, "the profession is gradually feminizing", "is becoming younger" and at the same time suffers from "lowering of the level of professionalism, which depends directly on level, type and quality of education" (Svitich 2000: 182, 190). 
The abolition of state regulation of the media sphere set in motion the journalist labor market: It became an open, alternative, self-regulative field. As the managing director of the St. Petersburg Union of Journalists said:

The conditions changed very much. In order to earn one should alternate between three-four newspapers, to write continuously, even then it is possible that you will not be paid or suffer delays.

The experts emphasized the difference in the working conditions between journalists in the center, St. Petersburg and the provinces. Thus, in the words of deputy Sergey Shelin of the daily Vechernii Peterburg:

In Moscow a journalist has good conditions, in the provinces he has bad conditions, in St. Petersburg he has bad conditions. However, the level of salaries of the St. Petersburg journalists is higher than an average salary. The salaries are earned differently: the work is done for several editions at once. That is not a sign of professionalism but a sign of unhealthy development of the city's market. As in Moscow to get money in one place it is not possible for subsistence. It is no secret that a significant part of journalists are corrupt on the personal level, they produce commissioned materials advertising commercial undertakings.

The interviews with journalists confirmed that practically everybody produced commissioned materials for the sake of money; every third respondent had a second job in other media or in the PR sections of commercial organizations. The average salary of city journalists was 2000-4000 rubles (50-100 US dollars). This amount was not enough for living in St. Petersburg. In the words of Alexander Yurkov, deputy of the daily SanktPeterburgskie Vedomosti (interview 1998): "The main problems became the corruption of the journalist community and the lack of professionals on the editorial staff". Concerning corruption, the study examined the journalists' perceptions of how it is possible to correlate professionalism and corruption in the journalist's profession, which essentially is destined for public interests, not private ones. The journalists practically unanimously justified corruption in professional practice and society. As one respondent argued: "If you live in such conditions where everything from top to bottom is penetrated by corruption then it is, naturally, a question of living in poverty or living normally - a matter of survival".

The journalists resorted to those rules that corresponded to the policy and culture of their concrete media. One of the experts noted that: "Nobody can say that gentleman Minkin [the famous scandal journalist] is a pariah among journalists. For some he is a pariah, for others he is a noteworthy journalist". The Code of Ethics adopted by the Congress of Journalists in 1994 was little known among the city journalists; the editorial offices did not introduce it in their normative documents. Both the experts and the journalists were full of skepticism concerning professional organizing. On the one hand, they criticized the present St. Petersburg Union of Journalists for its inability to help, for instance, there was a sad case involving getting a 'defense card' for the journalists. Many talks were held there, but with no result. They also recalled that the Union did not help in other difficult situations, for instance when the press journalists were on strike and television journalists of the 5th channel were subjected to a militia search (obysk) in their workplace. On the other hand, the professional environment had little interest in the other associations such as the Glasnost Defense Fund. Below is an excerpt from an interview with a journalist from the daily Vechernii Petersburg: 
The thought that some fund will feed me or defend my rights calls up a smile. We are very far from that in order that the real strength would be ready to consolidate some rules of conduct, some ethics, defense among the journalists. I am a member of the Union of Journalists, a member of the Union of Political Journalists. The Union of Journalists is a place for events, to sit in a restaurant; the other unions are clubs for interests where we communicate, but we are far from defending each other.

\section{Conclusion}

St. Petersburg journalism of the 1990s experienced a qualitative transformation, passing from the Soviet, state model to the market model of development. The dynamic growth of the markets of media, advertisement and labor resources created premises for its economic independence from the local authority. Here more than $90 \%$ of media were non-state, which meant they could not be managed directly by officials. In the common media budget, the ratio of state to advertising money of 22:77 indicated that the development of the media sector was proceeding in the manner of business enterprises. Below, the picture represents the city media budget in 2000 (Public expertise 2000: 677).

In turn, this presupposed the transformation of the journalist's product from one of ideological to one of factological contents, when information like any other goods is destined for the satisfaction of consumer demand. The narrow profile of various editions and programs sought their target audience and in this way covered a wide circle of interests and tastes. The development of information and communication technologies (computer, cable and satellite TV, video, short-wave broadcasting, mobile telephone connection, Internet) broadened the media infrastructure and correspondingly their potential in the delivery of informational and advertising services. Journalists could work as freelancers avoiding "serfdom" dependence on the staff position.

\section{Structure of City Media Budget}

Advertising Money $78,34 \%$

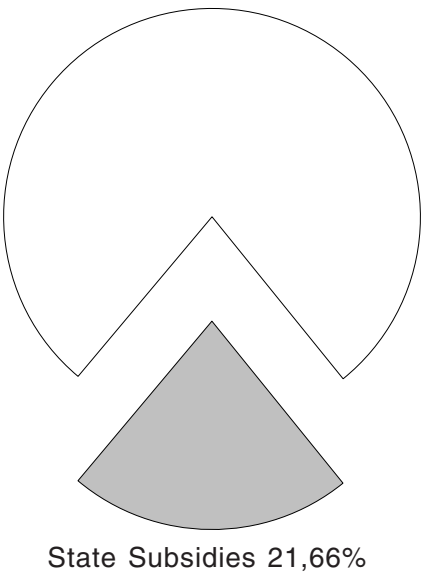

Source: Public Expertise 2000.

On the other hand, the specifics appeared in that, in Russia as a whole and in the region in particular, the political situation was not stable and quite personalized. It depended much on who was in power. In the 1990s, St. Petersburg had three different leaders re- 
sponsible for the development of the city: B. Gidaspov (1990-1991), A. Sobchak (19911996) and V. Yakovlev (1996 -2003). The data for the study gathered in 1998-2001 reflect that concrete temporal situation when the administrative resources completely belonged to the governor. His indisputable influence, often mediated, spread to the majority of media independent of the form of ownership and the owner. Although in 1999 and 2000 the city occupied the second place in Russia after Moscow concerning the level of freedom of mass information (the corresponding indices were $50.5 \%$ and $50.2 \%$ ), the experts put the city into the group of the semi-closed regions, which were in the majority in Russia (44). In these regions, access to information was often closed for journalists (Public expertise 2000: 14-17). The character of media conflicts revealed that the authorities had little respect for journalists, the most numerous infringements being connected with searching and receiving information, accreditation, interference in professional activity, obstructing the journalist's work. Nevertheless, the authorities did not forget to participate in the privatization of the basic news media and to make their presence felt with the founders of the other media. That is, viewing the media as a political tool and journalists as propagandists remained the principle.

The official salary of journalists remained very modest, but the majority had additional sources of income such as a second job and paid commissions (hidden advertisement, black PR, commissioned articles). Between the official salary of the staff job and additional income in the second job, there was a huge difference amounting to, for instance, 500 to 4500 rubles (12 to 112 US dollars), in the case of one of the respondents. Likewise the approach to the basic job was often to treat it as hackwork. The competition had not yet appeared between journalists, and opportunities for earning were ample. Corruption was condoned as a social and professional norm. The requirement for uniting and self-regulation did not mature, the professional community was atomized and everybody was busy with his/her own problems of survival. For the journalists, the audience remained little known, perceived rather as an electorate (during political campaigns) and a mass thirsting for spectacles (everyday life). The division of labor among journalists was between: propaganda making (elections of different levels practically annually) in the serious editions and entertaining in mass programs and print. Both functions were self-sufficient and did not strive for objectivity as a basis for the journalist's approach.

It can be said that St. Petersburg journalism reflected the hidden conflict between economic and technological innovations of the media sphere, on the one hand, and the former Soviet stereotypes and behavior models of the authority and professionals, on the other. Moreover, both political (traditional) and apolitical (new) journalism successfully worked with the authorities, who predicted journalists' lack of concern about truly informing citizens and making an effort toward the development of an open society. It revealed that the tradition of Soviet (state) journalism (in the sense that media serves the needs of the authorities, not a public) remained immutable.

However, the transformation of Russian society and media is not over, and it is very interesting to study what is still to come. Attempts to estimate the transformation at the end of the 1980-1990s as well the first term of the presidency of Vladimir Putin continue to be undertaken both in the West and Russia. After the successful re-election of Vladimir Putin for a second presidential term in March 2004, it was no accident there at once emerged a question about who will follow in 2008. The present Constitution (1993) restricts the ruling of the same person to two terms. Putin's reforms over the increasing role of the State led to sterilization of the political field: "the political communication was cut down" (Genisaretsky 2004: 18); the Parliament is a "chimera" for which there is no difference between communists and liberals (Naishul 2004: 13). In the 
opinion of sociologist Simon Kordonsky (2004: 7), in Russia there is no society in the traditional political science sense: There is a society that has been created by the State (by different structures of the state apparatus). Those organizations representing the civil society exist as a rule by means of foreign money, but once "a flow of money from abroad stops, an activity of these organization stops at once. They are artificial".

Some Russian scholars argue that Russia is suited "in Hobbes's structure where rights are made over to the State and are developed by the State" whereas in the Western democracies there is Locke's structure of the social contract when the State is enlisted as an agent for the ensuring of those rights about which the people and different groups of the population agreed (Auzan 2004: 21). In the given situation, the economist Vitaly Naishul (2004: 13) proposes to us, researchers, to pay more attention to what will ripen outside the center of power, "beyondwhat Putin does".

\section{Notes}

1. The study was presented as a Licentiate thesis in 2002 in the Department of Journalism and Mass Communication at the University of Tampere (Juskevits 2002). In 2003, the author adopted her mother's surname, Pasti, and this article is published under the author's new surname.

2. The project Public Expertise: Anatomy of freedom of speech directed by the Union of Journalists of Russia was developed by a number of public organizations including Glasnost Defense Fund, the Media Law and Policy Center of School of Journalism MSU and Internews Europe in Russia.

\section{References}

Auzan, Alexander (2004) 'The Economic Foundations of the Civil Institutions': Public Lectures in Polit.ru: http://www.polit.ru/research/lectures/2004/05/19/auzan.html

Bogdanov, Nikolai G. \& Vyazemsky Boris A. (1971) Spravochnik Zhurnalista [The Handbook of a Journalist]. Leningrad: Lenizdat.

Bogdanov, Vsevolod (2001) 'Otkrytoe pismo Soyuzam Zhurnalistov respublik, krayev i oblastei Rossiiskoi Federatsii' [The open letter to Unions of Journalists of Republics and Regions of the Russian Federation]. Zhurnalist 8: pp. 61-63.

Genisaretsky, Oleg (2004) 'Project and Tradition in Russia': Public Lectures in "Polit.ru": Http:// www.polit.ru/research/lectures/2004/04/08/gen.html

Juskevits, Svetlana (2002) Professional Roles of Russian Journalists at the End of the 1990s. A Case Study of St. Petersburg Media. Unpublished licentiate thesis, University of Tampere, Department of Journalism and Mass Communication: http://tutkielmat.uta.fi/pdf/lisuri00006.pdf [The monograph A Russian Journalist in Context of Change. Media of St. Petersburg in Russian by Svetlana Pasti 2004, University of Tampere].

Kordonsky, Simon (2004) 'Social Reality of Contemporary Russia': Public Lectures in Polit.ru: Http:// www.polit.ru/research/lectures/2004/05/11/kordon.html

Kuzin, Vladilen I. (1998) Psikhologicheskaya kultura zhurnalista [The psychological culture of a Journalist]. Sankt-Peterburg: SPbSU, Fakulty of Journalism.

Media in CIS (1999) 'Russia', http://www.internews.ras.ru: pp. 188-241.

Naishul, Vitaly (2004) 'An Author of Voucher about Liberal Reforms': Public Lectures in Polit.ru: Http:// www.polit.ru/research/lectures/2004/04/21/vaucher.html

Namsaraeva, Alla (1998) 'Sankt-Peterburg: Odnim Budet Tyazhelo, A Drugue Pogibnut' [It will go hard with some and others will perish]. Sreda 6 (August): 12.

Osnovnye itogi raboty administratsii Sankt-Peterburga za 2000 god i zadachi na 2001 i posleduyushchie gody (The St. Petersburg Government Report on the Basic Results of the Work of the St. Petersburg Administration in 2000 and the Tasks for 2001 and Next Years). (2001) Sankt-Petersburg: Administratsiya Sankt-Peterburga.

Public Expertise: Anatomy of Freedom of Speech [Obshchestvennaya ekspertiza: Anatomia svobody Slova] (2000) Moskva.

Sredstva Massovoi Informatsii Sankt-Peterburga i Leningradskoi oblasti [Mass Media of St. Petersburg and the Leningrad Region] (1999) Sankt-Peterburg: SPbSU, Faculty of Journalism. 
St. Petersburg in the 1990's, Biannual Monitoring Review, December (2000) Economic Monitoring of North-West Russia, Helsinki School of Economics, http://www.hkkk.fi/ecomon

Svitich, Luiza G. (2000) Fenomen Zhurnalizma (Journalism Phenomenon). Moskva: MGU/IKAR.

Vartanova, Elena (2001) 'Post-Soviet Media Model in Russia: Diversity of Structures, Variety of Pressures' in Yassen N. Zassoursky and Elena Vartanova (eds) Media for the Open Society. Moscow: Faculty of Journalism/IKAR, pp. 121-138.

Voroshilov, Vladimir V. (1999) Zhurnalistika (Journalism). Sankt-Peterburg: Izdatelstvo Mikhailova V.A.

Zassoursky, Yassen N. (ed) (2001) Sistema Sredstv Massovoi Informatsii Rossii [Mass Media System in Russia]. Moskva: Aspekt-Press.

Zassoursky, Ivan (2002) 'Media and Power: Russia in the Nineties', in Kaarle Nordenstreng, Elena Vartanova and Yassen Zassoursky (eds) Russian Media Challenge. Helsinki: Kikimora, pp. 73-91.

Zassoursky, Ivan (2004) Media and Power in Post-Soviet Russia. Armonk, New York, London: M.E. Sharpe. 